\title{
Instances of Belief in Fate in South India
}

\author{
By CARL GUSTAV DIEHL
}

Fate is blind, predetermined and inescapable. A search for such beliefs in South India may at first sight seem vain. There are many beliefs with one or two of the characteristics mentioned, but it is doubtful whether all three are ever to be found in a single doctrine or attitude.

Man's life is predetermined by Karma. The deeds of an earlier existence bear their fruits in the present life. That is why the poor man is poor and the rich is happy with his wealth and good fortune. One man is born a brahman and another spends his days as a pariah. The law of Karma has spread in the wake of Buddhism all over the Indian continent and far beyond, whereas its complement and presupposition Samsara for the most part appears as an intellectual conception with little foundation in popular belief. But Karma is not blind. On the contrary it is absolutely just, and for that very reason inescapable. This is, however, modified in so far as good deeds are both possible and profitable. The fatal consequences of the Karma of previous births end with this span of existence. Life hereafter will depend on the fruits of accumulated Karma here and now.

Man's life is subject to the influence of the stars. While Karma is retrospective the position of the planets at the time of birth forms a clue to the coming vicissitudes of life. Popular belief does not ask any questions about the power behind the movements of the stars. The thoughts of ordinary men halt with the predictions of the horoscope. They are led by them to feel anxiety or hope and, which is more important, to take precautions and counteraction. The horoscope is a kind of birth certificate. Its importance is never greater than at the time of marriage when there must be agreement, poruttam, between the horoscope of the bride and the bridegroom. To ensure this the yearly calendar, or more often an astrologer is consulted. 
The course of a man's life is determined by the movements of the planets in the lunar mansions and so is every hour of the day. Mukürttam in Tamil, from the Sanskrit muhürta, has come to mean an auspicious hour and will be observed when any important transaction and above all the main wedding ceremony takes place. There is no explanation of why the planets are positioned just as they are on the important occasion. Blind forces are operating. But the consequences are not altogether inevitable. It would be wrong to say that the planets are merely warning signs. Their influence is real, otherwise they would not have ceremonies addressed to them nor be the objects of worship. On the other hand, because they have become gods they are approachable. Their attitude can be softened and their decisions altered. In every Siva temple the nine planets, navagrahas, are found in a group where no one faces the other. Circumambulations are performed around them and offerings are brought to them. There are rituals for the mollification of Saturn and for bringing discordant elements of two horoscopes into harmony with one another. Talismans and amulets can counteract the influence of the planets, and thousands of advertisements similar to the following may appear in the papers: "Raj astrologer, Calcutta, has acquired unusual power through Yoga and Tantra whereby he can avert the evil influence of the planets." The common use of amulets and talismans implies a belief in a blind predetermination which can be controlled in a mechanical instrumental way.

These ideas exist all over India and find their expression in the languages of the South as well as of the North. Many Tamil sources equalize Karma and fate and destiny and quote as alternatives Sanskrit words like adrșta, the invisible or unforeseen, apūrva, that which has no beginning, prōrabdha, that which has commenced, daiva, that which belongs to the gods.

There are, however, some words in Tamil with no etymological connection with the Sanskrit language. They may add another dimension to the belief in fate. It is the purpose of this paper to examine the usages of such words as $\bar{u} \underline{l}$, vakai and $k \bar{u} r \underline{r} u$ with a view to indicating the concepts they stand for.

$\bar{O} \underline{l}$ is found with various meanings in old Tamil literature in works like the Kurạạ, Pưranānuựu, Kalitokai, Pattupātțu, Mañimēkalai. ${ }^{1}$ It is usually

1 See Tamil Lexicon, Madras, sub voce. 
considered to be a synonym of Karma or the fruit of Karma. There is reason, however, to believe that these renderings are oversimplified adaptations to the concepts of the Sanskrit culture.

The root $\bar{U} \underline{L}$ when used as a verb means 'grow old' and 'decay' and the Madras lexicon has as the first meaning of the noun 'that which is pristine, of long date'. In the second and third meanings it refers to Karma and its fruit. Transferred meanings are evident in the following definition: 'rule, i.e. long standing custom, maturity, time, end'. A derivative $\bar{u} l i$ is 'time of universal deluge, aeon, world' and then 'fate' and 'regular order'.

The Madurai Lexicon of $195^{6}{ }^{1}$ has 'the end of the world' as the first meaning and then similar definitions to those in the Madras lexicon but also gives for both $\bar{u} \underline{l}$ and $\bar{u} \underline{l} i$ the usual word for fate, viti (=Sanskrit vidhi).

There are many composite nouns which contain an explicit reference to Karma like $\bar{U} \underline{l}$ vinai, which can be rendered as 'old deed'. Deeds of former existences are meant. $\bar{U} \underline{l}$ viti is a mixture of Tamil and Sanskrit translated 'deed done by a soul in a former existence'.

The oldest reference made in the lexicon is to Puranänüru from about the beginning of the Christian era. In 29:22 the meaning is 'rule' or 'conduct' which contains the promise of wealth and good fortune:2 "May your action (O, King) be in conformity with customary behaviour when coupled with qualities of friendliness" would be a translation of the stanza. It is important to notice that $\bar{u} \underline{l}$ is here something you can choose or follow, with the good fortune hinted at by the commentator as its promised fruit.

It is not possible to follow the early history of the word. Our concern is chiefly with its connotation of fate interpreted as the fruit of Karma. In this connection two texts are immediately relevant. First of all there is a chapter in the Kural with the heading $\bar{U} \underline{l}$ (slokas $37 \mathrm{I}-38 \mathrm{o}$ ). Then we find in a collection of 9000 proverbs made by John Lazarus (Madras I894) five beginning with $\bar{u} \underline{i}$ (op. cit. 2088-2092).

The chapter in the Kural dealing with $\bar{u} \underline{l}$ begins with a definition by the commentator Parimelalakar dating from the $\mathrm{I} 2$ th century. His explanation is based on an older work of etymology, Pirayöka Vivëkam. " "This work

1 Tamil Pêrakaräti published by the Madurai Tamil Sangam.

2 Puranānuru, Madras 1947 , p. 85 , commentator.

3 Vativelu Cettiyar's edition p. 418 note. 
explains the agreement between Tamil grammar and Sanskrit grammar" says Singaravelu in his encyclopedia Abhidhana Chintamani. The information gives us reason to suspect an adjustment in meaning not without significance for the interpretation of $\bar{u} \underline{l} . \bar{U} \underline{l}$ is said to be the rule, niyati, which visits the consequences of deeds upon the doer and upon nobody else. The same commentator mentions some synonyms of which the first, $p \bar{a} l$, means share, attributed portion, and the last, viti or fate, has a Sanskrit origin suggesting 'produce, fix, give'. The relation to Greek expressions of a similar meaning like moira and aisa is obvious. As has already been stated the Tamil language has another word in the neuter gender of the same meaning, namely kiurrru. This is translated 'Yama, the king of death', although it is derived from $k \bar{u} r u$ meaning 'portion, lot, share'. A more common word is vakai with the same meaning, which occurs in stanza 377 as verbal noun, verbal adjective and noun. The three uses of the same root are hidden in this rendering by Drew and Lazarus: " $\ldots$ as it has been determined by the Disposer"..2 Literally it could be translated "... according to the portion apportioned by the apportioner". As regards this last word, a grammatical usage recorded in Tolkappiyam, the classical work on Tamil grammar and the oldest extant literary work in Tamil, may be relevant. Some words can have a personal as well as a neuter ending, like kälam which both in this neuter form and with a masculine ending, kälan, is translated Yama as well as 'time'. The 'Disposer' could in other words have a neuter form and stand for a power of fate having no other function than causing events to happen as they do, just like kürru. Similar is teyvam, from the Sanskrit deva, which in its neuter form comes close to the Latin numen but without its numinous qualities. In the language of ordinary people teyvam is the unknown power behind happenings. There is as a matter of fact little difference between this and the common Christian expression katavulin cittam, 'the will of God', which is often taken as something inescapable to which one has to yield of necessity. Kural 6r9 illustrates the concept of teyvam: "Even if (an attempt) is doomed to failure through the divinity (teyvam) it will be its own reward since it is a genuine effort." The commentator significantly enough equates teyvam with $p \bar{a} l$ vakai, i.e. the two words for lot or portion used in a sense equal to Fate.

1 Tamil Lexicon, s.v.

2 Tirukural, Madras 1952, p. 77. 
The author of the Kural knows no god but one may not assume his adherence to a rationalistic conception like Karma either. In addition he is opposed to a ruthless predeterminism.

The first stanza of the chapter on $\bar{u} \underline{l}$ in the Kural qualifies $\bar{u} \underline{l}$ as positive and negative, $\bar{a} k \bar{u} \underline{l}$ and $p \bar{o} k \bar{u} \underline{l}$. Positive $\bar{u} \underline{l}$ makes man trustworthy whereas negative $\bar{u} \underline{l}$ makes him lazy and indolent. In the next stanza the negative $\bar{u} l$, here called $i l l a v u \bar{u} l$, is said to make him ignorant and stupid, even though he may have acquired all kinds of knowledge. $\bar{A} k \bar{u} \underline{l}$ on the other hand wherever it occurs enlarges the knowledge even of an ignorant man. The third stanza states that a man may have studied however many learned books, his negative $\bar{u} \underline{l}$ will cause his natural foolishness to increase.

The fourth stanza makes another distinction however: "The nature of the world is twofold. There is the world of wealth and the world of knowledge." The commentator connects this distinction with $\bar{u} \underline{l}$ by saying that knowledge is not necessary as an aid to acquiring wealth.

In the English translation of the Kural, made by Drew and Lazarus, ${ }^{1} \bar{u} \underline{l}$ is rendered 'fate' which as has been shown already is in line with the interpretation of Tamil commentators. This is borne out by the fifth stanza where all three aspects of the concept of fate can be found. It says that in man's efforts to acquire wealth everything favourable becomes disadvantageous and everything disadvantageous becomes favourable - "through the power of $\bar{u} l$ ", adds the commentator. What happens is predestined, inescapable and blind, because there is no explanation. H. A. Popley's introduction of the word karma into his translation is quite arbitrary. ${ }^{2}$ The efforts of men are of no use according to 376 : "That which is not your portion ( $p \bar{a} l-$ "the share apportioned by teyvam, i.e. $\bar{u}$ lor fate", says the Tamil Lexicon s.v. quoting from Tolkāppiyam Colatikaram 58) will not remain although you guard it carefully, and what is yours-'through $\bar{u} l^{\prime}$, adds the commentatorwill not leave you even if you pour it away." According to stanza 377 the very enjoyment of the good things in the world by those who have made their millions is determined by the Disposer. Even the way of renunciation is denied to the destitute who are victims of fate, says 378 . The implication seems to be that poverty could lead to an ascetic life and thus be the cause of

1 Madras 1949, reprint of an old edition.

2 The Sacred Kural, Ca'cutta I931, p. 52. 
ultimate progress. But the inexorability of fate will prevent even such an escape. It is worth noticing that Parimēlalakar uses the plural $\bar{u} l k a l$.

To complain of one's misfortunes is pointless. A touch of the serene indifference of Buddhism is found in stanza 379, where a mild reproach is directed against those who gladly accept good fortune but resent an adverse fate. "Nothing is stronger than $\bar{u} \underline{l}$. If you try to get around it, $\bar{u} \underline{l}$ will be in that very effort." Thus ends the chapter in the Kural. Vativelu Cettiyar explains, "Whatever befalls the soul happens because of $u \underline{u}$ ". ${ }^{1}$

There is clearly no reference to Karma in the text of the Kural. The commentators' explanations sometimes turn in that direction, but even they more often interpret the word in terms of fate. The Kural could be expected to contain views on Karma in view of its depending on Sanskrit words like Kauțilya's Arthasáastra and also Jain or Buddhist traditions. ${ }^{2} \bar{U} \underline{l}$ is a wider concept of something old and inescapable. It will consume the world as $\bar{u}$ lttti , the fire, which in Civaka Cintāmani 973 is the equivalent of vadava mukhägni, the fire of Aśvini, the mare, the mother of the Aśvins, which will consume the world at the end of the aeon. For Karma the common word in Tamil is vinai which is used in Kural $3^{67}$ rather on the lines of Karma. "If a man thoroughly cuts off all desire, the deeds (vinai) which confer immortality, will come to him in the path in which he seeks them."'3

The meaning of the word $\bar{u} \underline{l}$ is not exhausted only by references to the Kural, nor is any attempt to do so intended here. It might, however, also be relevant to consult the list of proverbs. These proverbs contain the variant $\bar{u} \underline{l} i$ along with $\bar{u} \underline{l}$. The dictionaries offer slightly different renderings of the two forms but it is clear from the commentator on Civaka Cintämani $\mathrm{I} 49$ and $\mathrm{II} 38$, for example, that $\bar{u} l i$ is a permissible variant of $\bar{u} \underline{l} .4$

It says much for people's need for encouragement that out of the five proverbs beginning with $\bar{u} \underline{l}$ or $\bar{u} \underline{l} i$ three speak of the possibility of modifying fate with good courage and strong efforts as in, for example, "Even if $\bar{u} \underline{\imath} i$ is powerful, don't relax your efforts." One proverb, however, repeats in question form but with negative response expected what is already stated in the

1 Tirukural, Madras I9i9, p. 428.

2 M. Winternitz, Geschichte der indischen Literatur, Leipzig ı920, III p. 580, and H. A. Popley, The sacred Kural, p. 22.

3 Drew and Lazarus' translation.

4 Caminataiyar's edition, Madras 1922, p. 342. 
Kural: "Can there be anything stronger than fate?" J. Lazarus uses the word fate throughout for $\bar{u} \underline{l}$ and $\bar{u} \underline{\imath} i$.

One proverb is puzzling even to Tamil scholars. No. $208_{5}$ in the collection of Lazarus reads: $\bar{U}$ likkāayccal atikam ānal cūñiyakkāran kollai. M. Lazarus gives the following interpretation: "One's extremity another's opportunity." This is a very free rendering. Literally it means: "If $\bar{u} \underline{l} i$ fever is high the sorcerer will have gain." On submitting the proverb to three Tamil scholars and Pandits, three different interpretations were received. It might be worth while giving them in extenso as a small contribution to Tamil research.

I. A Tamil pandit living in Madras writes: "When in the country contagious fever is raging, the sorcerer (cüniyakkäran ) alias the mantra reader (mantravãti) gets a good income. Common people fearing foot and mouth disease seek the help of mantra readers to remove it. That is the reason." Two pandits from Madurai write:

2. "When at the destruction of the world disastrous conditions prevail, the deceitful sorcerer, bent on robbery, will make use of these conditions to cheat the people, make them confused and deceive them.

It is like this: When on board a ship, tossed by a heavy storm, people in the grip of fear run hither and thither leaving their belongings, some hypocrites will profit from their distressed state and steal many valuables. This is an application of the proverb."

3. "A cunniyakkäran is a man who contrary to God (vallan) brings things about with the help of certain powers (caktikal).

Kollai means gaining a great victory in bringing things about. Ūlikkayyccal means the trouble that comes through not walking in the way which God (vallan) has apportioned (vaku1).

There was a king who was a cruel ruler. He did not care for the happiness of the people of his country but in his own interests accumulated much wealth, forgetting how he should have behaved, going astray from the good path and illtreating the people for his own good. Hunger and disease began to raise their heads and spread over the country. A neighbouring king seeing this state of affairs attacked that country with his small army, conquered it, and tormented the people still further, all according to this proverb."

1 Compare vakai mentioned above as 'lot, portion, established manner'. 
While all three agree in the application, there are obviously different opinions about the meaning of ülikkäayccal and cüniyakkäran. When people are in straitened circumstances ruthless men take advantage of the situation. But the circumstances indicated by $\bar{u} \underline{l} i$ and $k a \bar{a} c c a l$, which usually means 'heating, excess of heat, fever', are very differently illustrated as I) contagious disease, 2) the deluge, and 3) the unjust rule of a king. One pandit refers to $\tilde{u} \underline{\imath} i$ as deviation from approved conduct which may be a reference to Bhagavad Gita IV, 7: "Whenever there is decline of Law, O Bharata, and an outbreak of lawlessness, I incarnate myself", but in other cases $\bar{u} \imath i$ is something more unaccountable and of cosmic proportions.

To get a complete understanding of what $\bar{u} \underline{l}$ stands for, an analysis of a number of composite nouns should also be made. Here only one more phenomenon may be mentioned. In the Tamil encyclopedia of Singaravelu, called Abhidana Chintamani, there is a reference to ülvätimatam. The word literally means the religion, matam, of $\bar{u} \underline{l}$. Vãti is the same word as the common Sanskrit element found for instance in the Buddhistic sarvāstivādin, or advocate of the doctrine of real existence. "Ülvätimatam teaches that Karma is a deity for the reason that Siva always acts through or by means of Karma. $\bar{U} \underline{l}$ is Siva and $\bar{u} \underline{l}$ is Brahman. ${ }^{\prime \prime}$ The argument clearly aims at a rationalistic explanation of $\bar{u} l$ adapting it to the idea of Karma. After what has been said above, this means either an intended adaptation by Singaravelu or a late development. Even so it is of significance that $\bar{u} \underline{l}$ is identified with the ultimate power. What it really means and what it has stood for in the experience of the Tamil people has only been shown in a few examples. It cannot be a mere coincidence that $\bar{u} \underline{l}$ is for the most part translated as 'fate' or 'destiny', and the same can be said of its implications in the limited material presented here. $\bar{O} \underline{l}$ can safely be said to have suffered from an oversimplified arianization in the writings of commentators of a later date.

${ }^{1}$ Abhidhana Chintamani, s.v. 